\title{
Isoorientin induces apoptosis, decreases invasiveness, and downregulates VEGF secretion by activating AMPK signaling in pancreatic cancer cells [Corrigendum]
}

Ye T, Su J, Huang C, et al. OncoTargets Ther. 2016;9:

7481-7492.

The authors have advised that a number of errors were made in some of the figures within their paper.

Page 7485, Figure 2A, the corrected image for PANC-1 protein AMPK is:

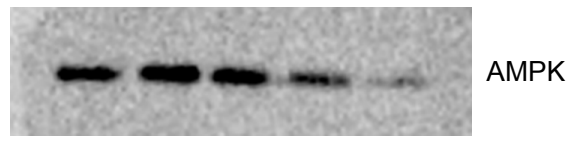

On page 7486, Figure 3 was incorrect. The correct figure is:

A

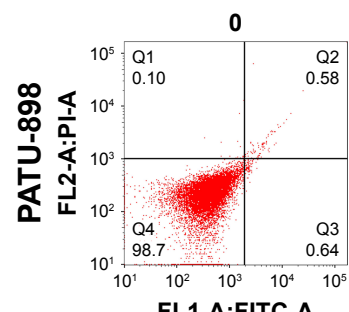

FL1-A:FITC-A
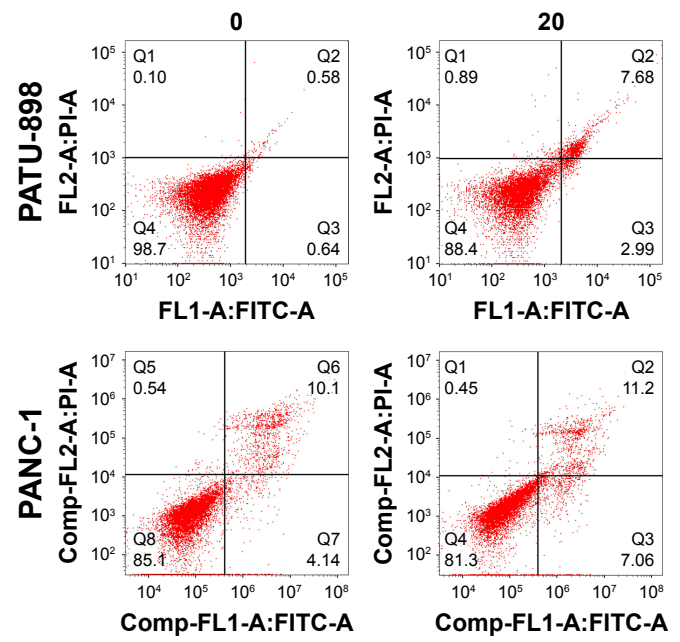

Isoorientin $(\mu \mathrm{M})$

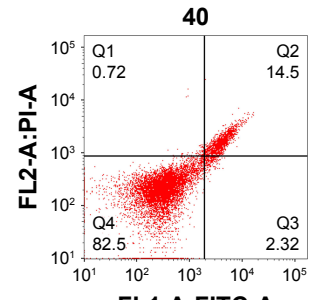

FL1-A:FITC-A
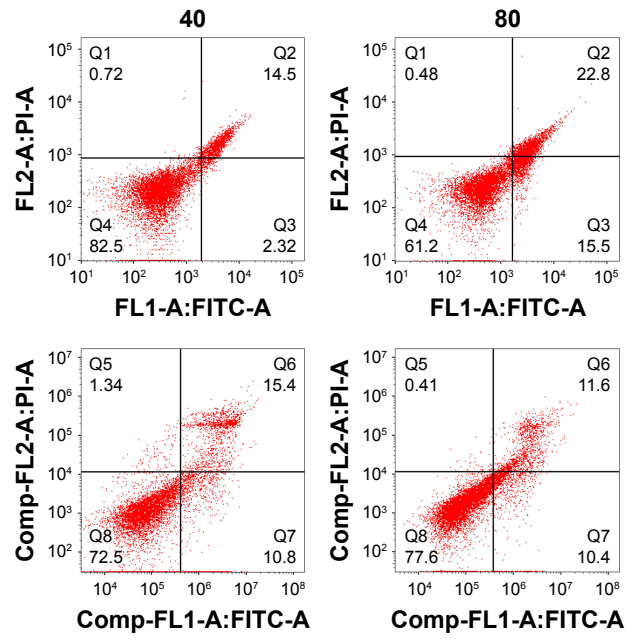

FL1-A:FITC-A
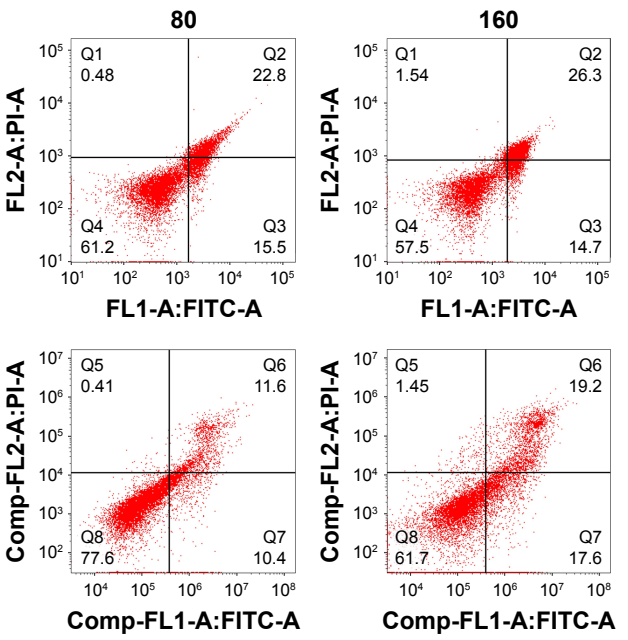

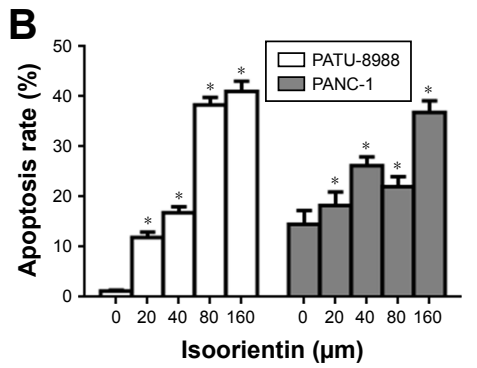

C

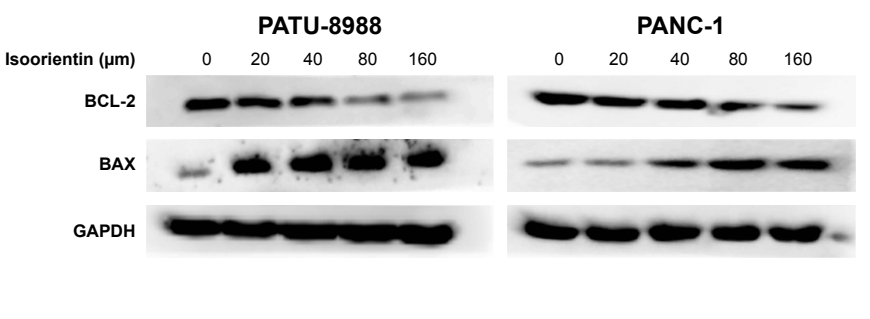



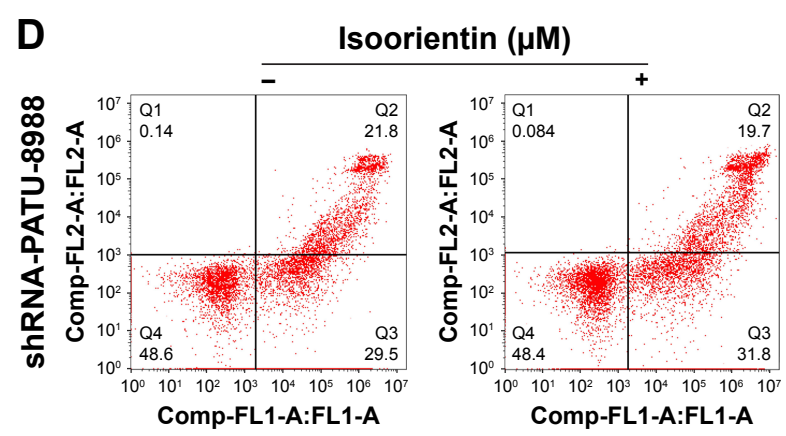

E
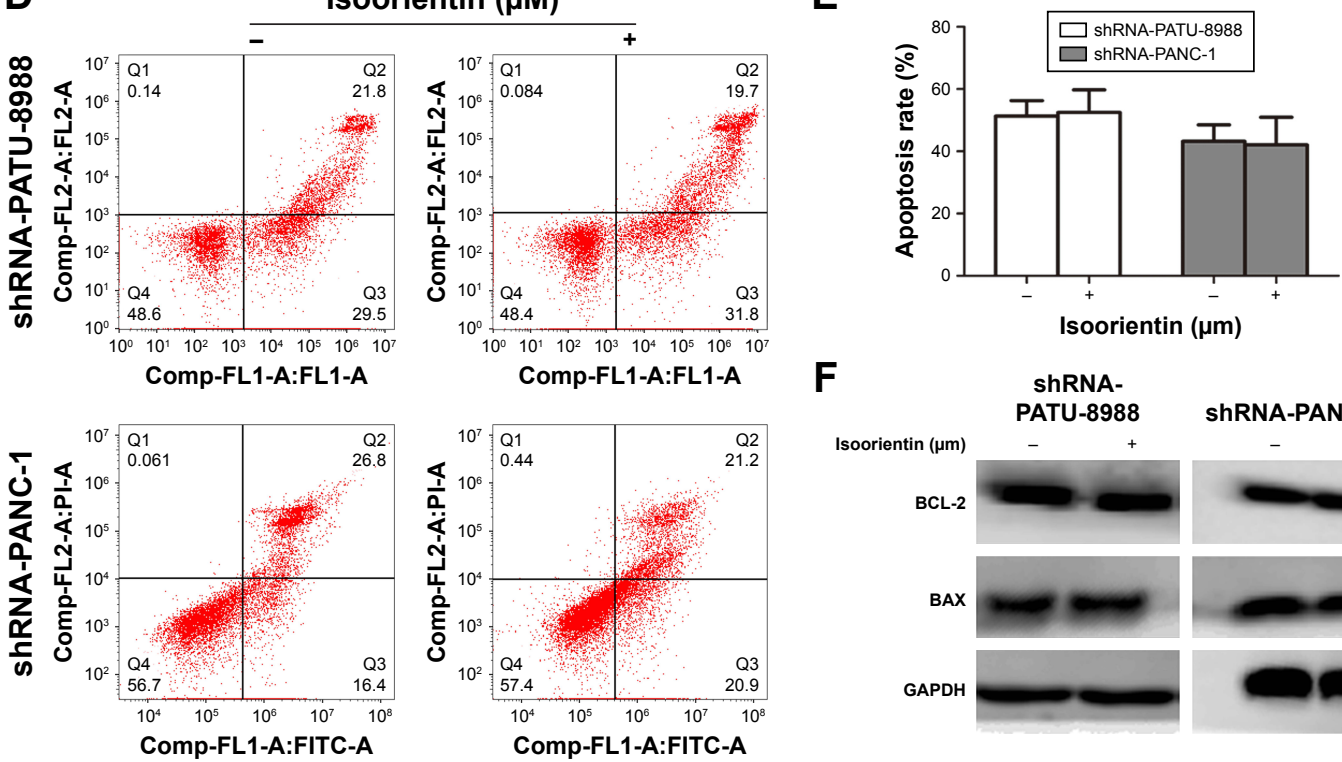

$\mathbf{F}$

ShRNA-

PATU-8988 ShRNA-PANC-1

Isoorientin $(\mu \mathrm{m})$

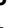
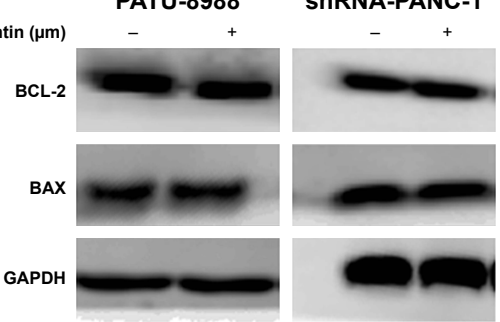

Page 7487, Figure 4B, the corrected image for PATU-8988 protein MMP2 is:

Page 7490, Figure 5B, Migration section, the corrected image for shRNA-PATU-8988 is:

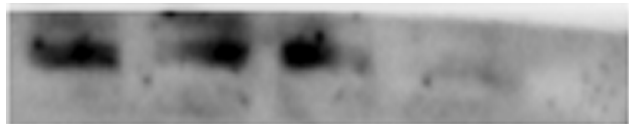

MMP2

Page 7488, Figure 4D, the corrected image for shRNAPANC-1 protein N-cadherin is:
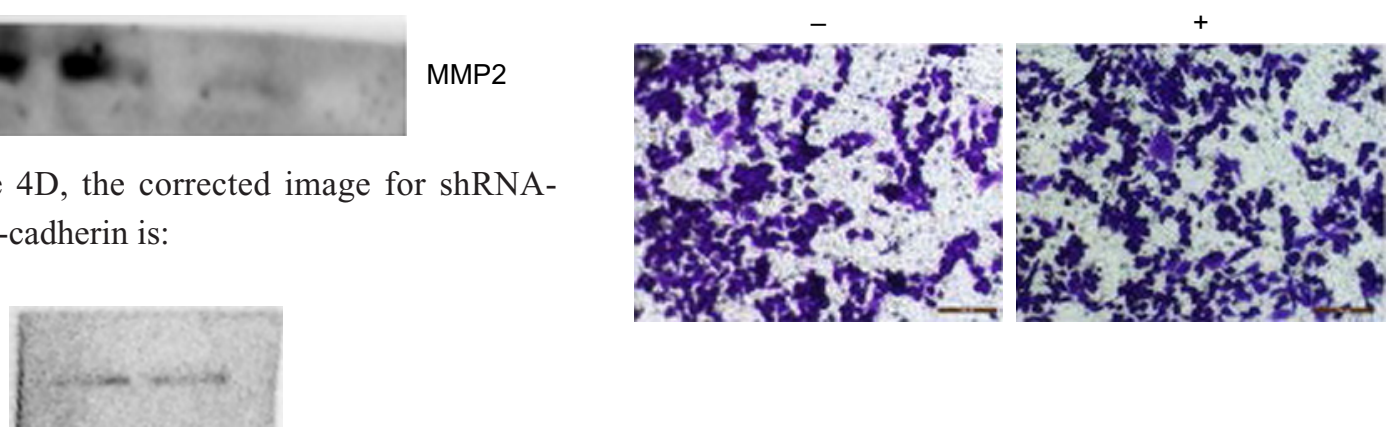

Page 7489, Figure 5A, Migration section, the corrected image for PATU-8988 at the concentration of Isoorientin$160 \mu \mathrm{M}$ is:

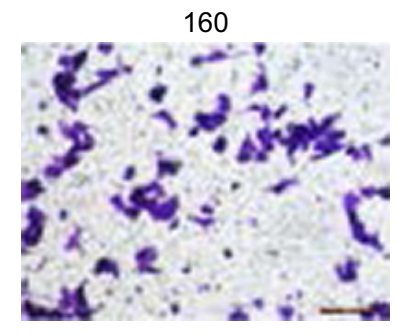

OncoTargets and Therapy

\section{Dovepress}

\section{Publish your work in this journal}

OncoTargets and Therapy is an international, peer-reviewed, open access journal focusing on the pathological basis of all cancers, potential targets for therapy and treatment protocols employed to improve the management of cancer patients. The journal also focuses on the impact of management programs and new therapeutic agents and protocols on

patient perspectives such as quality of life, adherence and satisfaction. The manuscript management system is completely online and includes a very quick and fair peer-review system, which is all easy to use. Visit http://www.dovepress.com/testimonials.php to read real quotes from published authors. 